\title{
Oxidants Increase Paracellular Permeability in a Cultured Epithelial Cell Line
}

Michael J. Welsh, D. Michael Shasby, and Russell M. Husted

With the technical assistance of Phil Karp and Philip Spory

Laboratory of Epithelial Transport and Pulmonary Division, Department of Internal Medicine, University of Iowa

College of Medicine and Veterans Administration Hospital, Iowa City, Iowa 52242

\section{Abstract}

Inflammation of epithelia is an important step in the pathophysiology of a wide variety of diseases. Because reactive oxygen metabolites are important effector molecules of acute inflammation, we examined the effect of oxidants on the barrier function of a cultured epithelium, Madin Darby Canine Kidney cells, by measuring the transepithelial electrical conductance, $G_{t}$, of monolayers grown on permeable supports. We found that $\mathrm{H}_{2} \mathrm{O}_{2}$, added directly or generated with glucose oxidase, increased $\mathbf{G}_{\mathbf{t}}$. Similar effects were observed with addition of xanthine and xanthine oxidase, a system which enzymatically generates superoxide radical $\mathbf{O}_{2}^{-}$. The oxidant-induced increase in $\mathbf{G}_{\mathbf{t}}$ was reversible if the exposure to oxidants was not prolonged ( $<20 \mathrm{~min}$ ), and if the concentration of $\mathrm{H}_{2} \mathrm{O}_{2}$ was $<5 \times 10^{-3} \mathrm{M}$. The increase in $\mathrm{G}_{\mathrm{t}}$ suggested that oxidants increase the permeability of the paracellular pathway, a suggestion supported by an oxidant-induced increase in the permeability to ${ }^{14} \mathrm{C}$-mannitol, which primarily crosses epithelia via the extracellular route.

In addition to functional changes in the epithelial monolayer, oxidants changed the cell morphology; after $\mathrm{H}_{2} \mathrm{O}_{2}$ exposure, the cells tended to pull apart, most prominently at their basolateral surfaces. These changes were heterogeneous with most areas showing no changes. Some of the morphologic changes could be reversed if the exposure to $\mathrm{H}_{2} \mathrm{O}_{2}$ was limited. We also observed a disruption of the normal pattern of the actin-cytoskeleton, particularly in the area of cell to cell junctions, as demonstrated by fluorescent staining of $f$-actin with rhodamine phallicidin.

These functional and structural findings indicate that oxidants increase the permeability of the paracellular pathway in a cultured epithelium. The changes can be reversible, and are accompanied by alterations in organization of the cell cytoskeleton. These studies demonstrate the dynamic nature of the interaction between epithelial cells and oxygen metabolites.

\section{Introduction}

Because of their ubiquitous location, epithelia are frequently involved in inflammatory processes. Furthermore, inflammation of epithelia appears to be an important step in the pathophysiology of a variety of diseases (1) including the adult respiratory distress syndrome; inflammatory bowel diseases; acute and chronic pancreatitis; and acute ischemic renal failure. In all of

Drs. Welsh and Shasby are Established Investigators of the American Heart Association. Address correspondence to Dr. Welsh.

Received for publication 31 December 1984 and in revised form 13 May 1985.

J. Clin. Invest.

(c) The American Society for Clinical Investigation, Inc.

$0021-9738 / 85 / 09 / 1155 / 14 \$ 1.00$

Volume 76, September 1985, 1155-1168 these diseases, the integrity of the epithelial barrier is compromised. Since the cell-to-cell contacts and tight junctions between epithelial cells make the epithelia an effective barrier, it seems that the response to inflammation might involve the junctions between cells.

Reactive oxygen metabolites are some of the most important effector molecules of acute inflammation. They contribute to edema formation in models of cutaneous vasculitis (2), and have been demonstrated to alter alveolar-capillary permeability in the lung when administered to either the alveolar or capillary surface $(3,4)$. Oxidants also contribute to the tissue response to radiation, ischemia, and cytotoxic drugs. In these processes oxidants have a variety of effects on cells, including cell lysis $(5,6)$, lipid peroxidation (7), activation of guanylate cyclase (8), and inhibition and uncoupling of cell membrane enzymes (9).

The purpose of this study was to examine the effect of oxidants on the barrier function of an epithelium. We chose the cultured renal epithelial cell line, Madin-Darby Canine Kidney (MDCK), ${ }^{1}$ for this study, because: $(a)$ its barrier function has been extensively characterized in our and other laboratories (10-12); (b) the cultured epithelium has an intact tight junction structure with a transepithelial electrical conductance $\left(G_{t}\right)$ low enough to make measurements accurate and reproducible in a given monolayer; $(c)$ the paracellular pathway is the predominant conductive pathway $(10,12,13) ;(d)$ the study of a cultured epithelium eliminates the potential problem of participation of nonepithelial cells in any response; and $(e)$ the epithelium is widely available and easily cultured.

\section{Methods}

Cell culture and solutions. MDCK cells were a generous gift of Dr. A. Spector, Department of Biochemistry, University of Iowa. We used cells between passage 69 and 73. Cells were grown in media containing Earle's modification of Eagle's minimum essential medium supplemented with $10 \%$ fetal bovine serum, gentamycin $\left(50 \mu \mathrm{g} \cdot \mathrm{ml}^{-1}\right)$, insulin $\left(1 \mathrm{mU} \cdot \mathrm{ml}^{-1}\right)$, and nonessential amino acids (media and tissue culture reagents were obtained from the University of Iowa Cancer Center). The cells were incubated at $37^{\circ} \mathrm{C}$ in a $5 \% \mathrm{CO}_{2}$-air atmosphere. Cells were harvested with $0.25 \%$ trypsin- $0.1 \%$ EDTA (Gibco 540, Gibco Laboratories, Grand Island, NY). We seeded the cells on 25-mm diameter polycarbonate filters ( $0.8 \mu \mathrm{m}$ pore size) (Nucleopore) at a density of $10^{6}$ cells filter ${ }^{-1}$. The filters were pretreated with gelatin (Sigma Chemical Co., St. Louis, MO) using the method of Postlethwaite, Snyderman, and Kang (14). For microscopic studies, the cells were grown on impermeable supports because the filters are nearly opaque, thus preventing a morphologic examination. Cells were plated on glass coverslips that were cleaned with dimethyl sulfoxide and double-distilled water and then coated with gelatin or human placental collagen (type VI, Sigma Chemical Co.). It is possible that cells cultured on impermeable supports have different functional

1. Abbreviations used in this paper: DDC, diethyldithiocarbamate; $\mathrm{G}_{\mathbf{t}}$, transepithelial electrical conductance; $\mathrm{J}^{\text {Man }}$, transepithelial mannitol fluxes; MDCK, Madin Darby Canine Kidney. 


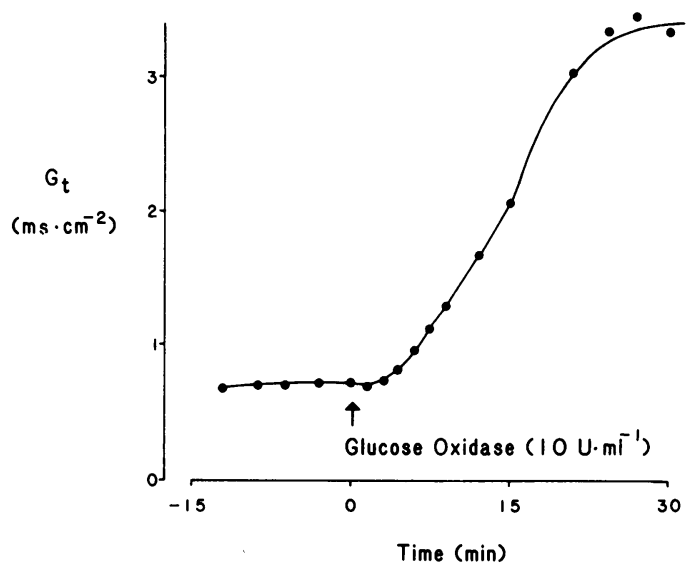

Figure 1. Time course of the effect of glucose oxidase on $G_{t}$. Glucose oxidase $\left(10 \mathrm{U} \cdot \mathrm{ml}^{-1}\right)$ was added to both bathing solutions at time zero.

characteristics than those grown on permeable supports. Although the formation of domes by cells on permeable supports indicates that at least some portions of the monolayers have an intact junctional complex, we cannot be sure that the monolayers are homogeneous in their junctional structure and transport characteristics. We used the cells 3-14 d after plating; no consistent functional differences were noted in this time frame.

For studies in Ussing chambers, the tissues were bathed in a Ringer's solution containing (in millimolars): $118.9 \mathrm{NaCl}, 20.4 \mathrm{NaHCO}_{3}, 2.4$ $\mathrm{K}_{2} \mathrm{HPO}_{4}, 0.6 \mathrm{KH}_{2} \mathrm{PO}_{4}, 1.2 \mathrm{CaCl}_{2}, 1.2 \mathrm{MgCl}_{2}$ and 10 glucose. The solution was bubbled with $95 \% \mathrm{O}_{2}$ and $5 \% \mathrm{CO}_{2}\left(\mathrm{pH} 7.4\right.$ at $\left.37^{\circ} \mathrm{C}\right)$. In the media used during microscopic observations, $\mathrm{NaCl}$ was substituted for $\mathrm{NaHCO}_{3}$, the solution was bubbled with air, and the $\mathrm{pH}$ was titrated to 7.4. Chemicals and reagents were added to both bathing solutions. Chemicals used in this study included: hydrogen peroxide (Fisher Scientific Co., Pittsburgh, PA) and glucose oxidase, catalase, xanthine, xanthine oxidase, allopurinol, and diethyldithiocarbamate (Sigma Chemical Co.).

Results are presented as means \pm SEM. Statistical significance was evaluated using paired or unpaired $t$ test or analysis of variance, as indicated. A $P$ value $>0.05$ was considered statistically significant.

Measurement of membrane conductance. For electrical measurements, the monolayers grown on polycarbonate filters were mounted between two halves of an Ussing chamber (1.5- $\mathrm{cm}^{2}$ surface area) (Jims

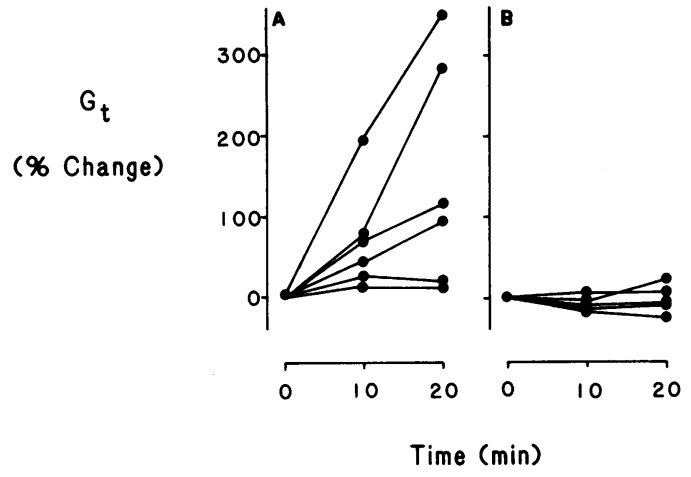

Figure 2. Effect of glucose oxidase $(A)\left(10 \mathrm{U} \cdot \mathrm{ml}^{-1}\right)$ on $\mathrm{G}_{\mathrm{t}}$. Monolayers shown in $B$ (catalase plus glucose oxidase) received catalase $10 \mathrm{~min}$ before addition of glucose oxidase (at time zero). The initial $G_{\mathbf{t}}$ was $3.0 \pm 2.0 \mathrm{~ms} \cdot \mathrm{cm}^{-2}$ in glucose oxidase monolayers and $3.9 \pm 2.0$ $\mathrm{ms} \cdot \mathrm{cm}^{-2}$ in the catalase-treated cells.

Instruments Mfg., Coralville, IA) as previously described (15). The solution bathing both surfaces of the monolayer was continuously circulated, bubbled, and maintained at $37^{\circ} \mathrm{C} . \mathrm{G}_{\mathrm{t}}$ was calculated from the change in voltage resulting from a constant transepithelial current pulse. Pulses were generated by current-voltage clamps (Bioengineering Dept., University of lowa) with a duration of $1 \mathrm{~s}$, a period of 10-60 s, and an amplitude sufficient to change transepithelial voltage by $\pm 10-20 \mathrm{mV}$.

To measure transepithelial mannitol fluxes, we added $5 \mu \mathrm{Ci}$ $\left[{ }^{14} \mathrm{C}\right]$ mannitol to one of the bathing solutions, waited $2 \mathrm{~h}$ for equilibration, and then took samples at 15 -min intervals. In these studies, $1 \mathrm{mM}$ mannitol was included in the bathing solutions. There was no consistent difference in mannitol fluxes from mucosal to submucosal solution or from submucosal to mucosal solution, therefore the two unidirectional fluxes were grouped.

Microscopic observations. For microscopic observations, cells grown on glass coverslips were mounted in a chamber on the microscope stage. The cells were perfused with Ringer's solution at a rate of $4 \mathrm{ml} \cdot \mathrm{min}^{-1}$ by gravity flow from reservoirs above the chamber. The perfusion reservoir was water jacketed so that the solution bathing the cells was maintained at $37^{\circ} \mathrm{C}$. We used an inverted microscope (Carl Zeiss, Oberkochen, Federal Republic of Germany) equipped with a differential interference contrast (Nomarski) optical system.

Table I. Effect of Xanthine and Xanthine Oxidase on $G_{t}$

\begin{tabular}{|c|c|c|c|c|}
\hline & & \multirow[b]{2}{*}{ Base-line $G_{t}$} & \multicolumn{2}{|c|}{$\mathrm{G}_{\mathbf{t}}(\%$ change $)$} \\
\hline & & & $10 \mathrm{~min}$ & $20 \mathrm{~min}$ \\
\hline & $n$ & $\mathrm{~ms} \cdot \mathrm{cm}^{-2}$ & & \\
\hline Control & (6) & $2.78 \pm 1.32$ & $+1 \pm 3$ & $-2 \pm 2$ \\
\hline $\begin{array}{l}\text { Xanthine }\left(5 \times 10^{-4} \mathrm{M}\right) \\
\text { Xanthine oxidase }\left(20.8 \mathrm{mU} \cdot \mathrm{ml}^{-1}\right)\end{array}$ & (9) & $3.12 \pm 1.05$ & $+32 \pm 7^{*} \ddagger$ & $+33 \pm 10^{*} \ddagger$ \\
\hline $\begin{array}{l}\text { Allopurinol }\left(10^{-4} \mathrm{M}\right) \\
\text { Xanthine }\left(5 \times 10^{-4} \mathrm{M}\right) \\
\text { Xanthine oxidase }\left(20.8 \mathrm{mU} \cdot \mathrm{ml}^{-1}\right)\end{array}$ & (6) & $3.32 \pm 1.34$ & $+8 \pm 8 \S$ & $+5 \pm 13$ \\
\hline $\begin{array}{l}\operatorname{DDC}\left(10^{-3} \mathrm{M}\right) \\
\text { Xanthine }\left(5 \times 10^{-4} \mathrm{M}\right) \\
\text { Xanthine oxidase }\left(20.8 \mathrm{mU} \cdot \mathrm{ml}^{-1}\right)\end{array}$ & (7) & $3.34 \pm 1.68$ & $+38 \pm 6^{*} \ddagger$ & $+72 \pm 8^{*} \neq \S$ \\
\hline
\end{tabular}

Values are means \pm SEM of the "base-line $G_{t}$ " taken before addition of xanthine and xanthine oxidase, and the percentage change in $G_{t}, 10$ and 20 min after addition. $n$, Indicates the number of monolayers. ${ }^{*}$ Different from base-line value by paired $t, P<0.01$. $¥$ Different from control values by analysis of variance, $P<0.05$. § Different from xanthine and xanthine oxidase by analysis of variance, $P<0.05$. 
Fluorescent staining of f-actin. Visualization of f-actin was performed as previously described, substituting rhodamine phallicidin (Molecular Probes Inc., Junction City, OR) for NBD phallicidin (16). We used epifluorescence (excitation wavelength $546 \mathrm{~nm}$, emission wavelength $>590$ $\mathrm{nm}$ ) to observe and photograph the f-actin staining pattern.

\section{Results}

Oxidants increase $G_{t}$. Fig. 1 shows the time course of the effect of glucose oxidase, a generator of $\mathrm{H}_{2} \mathrm{O}_{2}$, on $\mathrm{G}_{\mathrm{t}}$ in one monolayer. The $G_{t}$ was stable before addition of glucose oxidase to the glucose-containing Ringer's solution, and then increased fourfold after addition of $10 \mathrm{U} \cdot \mathrm{ml}^{-1}$. The effect of glucose oxidase on a group of monolayers is shown in Fig. 2. As a control, some tissues received catalase $\left(1,000 \mathrm{U} \cdot \mathrm{ml}^{-1}\right)$, an $\mathrm{H}_{2} \mathrm{O}_{2}$ scavenger, $10 \mathrm{~min}$ before addition of glucose oxidase. $20 \mathrm{~min}$ after addition of glucose oxidase, $G_{t}$ of the catalase-treated monolayers had decreased $2 \pm 9 \%$, while $G_{t}$ in the monolayers that had received glucose oxidase alone had increased $144 \pm 58 \%(P<0.05)$.

We also examined the effect of another oxygen radical generating system, xanthine and xanthine oxidase. Xanthine oxidase enzymatically generates the superoxide radical, $\mathrm{O}_{2}^{-}$, from xanthine. Table I shows the results. Addition of either xanthine or xanthine oxidase alone did not significantly alter $G_{t}$ and was not different from "control" monolayers that received no intervention. Addition of xanthine $\left(5 \times 10^{-4} \mathrm{M}\right)$ and xanthine oxidase $\left(20.8 \mathrm{mU} \cdot \mathrm{ml}^{-1}\right)$ significantly increased $G_{t}$ as compared with control tissues. To show that the addition of xanthine and xanthine oxidase increased $G_{t}$ by an oxidant mechanism, we added allopurinol $\left(10^{-4} \mathrm{M}\right)$, a xanthine oxidase inhibitor, to monolayers 5-10 min before adding xanthine and xanthine oxidase. Allopurinol prevented the increase in $G_{t}$, but had no effect on its own.

To test the possibility that intracullular antioxidant systems might be scavenging oxidants, we added diethyldithiocarbamate (DDC) $\left(10^{-3} \mathrm{M}\right)$, an inhibitor of intracellular antioxidant pathways (17), to the bathing solution $15 \mathrm{~min}$ before xanthine and xanthine oxidase. DDC did not alter base-line $G_{t}$, but did enhance the magnitude of the $G_{t}$ increase produced by xanthine and xanthine oxidase. These results suggest that intracellular oxidant defenses may partially protect epithelia from oxidant injury.

Table II. Effect of Hydrogen Peroxide on JMan

\begin{tabular}{ccc}
\hline & $\mathrm{G}_{\mathbf{t}}$ & $\mathrm{J}$ \\
\hline & $\mathrm{ms} \cdot \mathrm{cm}^{-2}$ & $\mathrm{nM} \cdot \mathrm{cm}^{-2} \cdot \mathrm{h}^{-1}$ \\
Control & & \\
Baseline & $7.7 \pm 0.7$ & $12 \pm 4$ \\
Control & $7.9 \pm 0.7$ & $16 \pm 3$ \\
Experimental & & \\
Baseline & $7.2 \pm 0.7$ & $8 \pm 3$ \\
$\mathrm{H}_{2} \mathrm{O}_{2}$ & $14.4 \pm 1.0^{*}$ & $132 \pm 68^{*}$ \\
\hline
\end{tabular}

Unidirectional mannitol fluxes were measured for $30 \mathrm{~min}$ during a base-line period, and then for 30-45 min during either a time control period or after addition of $\mathrm{H}_{2} \mathrm{O}_{2}\left(4 \times 10^{-3} \mathrm{M}\right)$. There were seven tissues in each group.

${ }^{*} P<0.05$ by unpaired $t$ test.

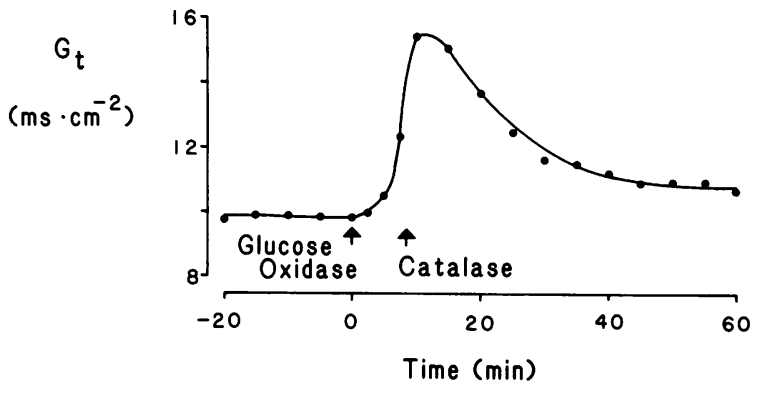

Figure 3. Reversibility of the effect of glucose oxidase on $\mathrm{G}_{\mathrm{t}}$. Glucose oxidase $\left(10 \mathrm{U} \cdot \mathrm{ml}^{-1}\right)$ and catalase $\left(1,000 \mathrm{U} \cdot \mathrm{ml}^{-1}\right)$ were added at the times indicated.

It is most likely that the oxidant-induced increase in $G_{t}$ results from an increase in paracellular (tight junction and lateral intercellular space) conductance because the predominant conductive pathway across MDCK cells is the paracellular pathway $(12,13)$. To provide further evidence for an effect of oxidants on paracellular permeability, we measured unidirectional, transepithelial mannitol fluxes before and after addition of $\mathrm{H}_{2} \mathrm{O}_{2}$. Mannitol is a large nonelectrolyte that is not actively transported (i.e., the two unidirectional fluxes are equal) and serves as a marker of paracellular pathway permeability in epithelia $(15,18)$. Table II shows that both $G_{t}$ and transepithelial mannitol fluxes $\left(\mathrm{J}^{\mathrm{Man}}\right)$ were stable with time. However, after addition of $\mathrm{H}_{2} \mathrm{O}_{2}$, both $\mathrm{G}_{\mathrm{t}}$ and mannitol flux increased, indicating an increase in paracellular permeability.

Reversibility of the oxidant-induced increase in $G_{t}$. To determine if the oxidant-induced increase in $G_{t}$ was reversible, we examined the effect of adding catalase to a glucose-oxidase treated monolayer; Fig. 3 shows the time course in one representative monolayer.

Fig. 4 shows the changes in $G_{t}$ observed when catalase was used to scavenge $\mathrm{H}_{2} \mathrm{O}_{2}$. Three groups of tissues were studied: one received catalase before $\mathrm{H}_{2} \mathrm{O}_{2}$ and had no change in $\mathrm{G}_{t}$; one received $\mathrm{H}_{2} \mathrm{O}_{2}$ alone and had a sustained increase in $\mathrm{G}_{\mathrm{t}}$; and one received catalase after $\mathrm{H}_{2} \mathrm{O}_{2}$ and had a reversal of the $\mathrm{H}_{2} \mathrm{O}_{2-}$ induced increase in $\mathrm{G}_{t}$. While these results show that the increase in $G_{t}$ could be reversed, this did not hold in all cases. For example, after $\sim 20-30$ min of $\mathrm{H}_{2} \mathrm{O}_{2}$ the changes were not reversed by antioxidants. In addition, if large increases in conductance had

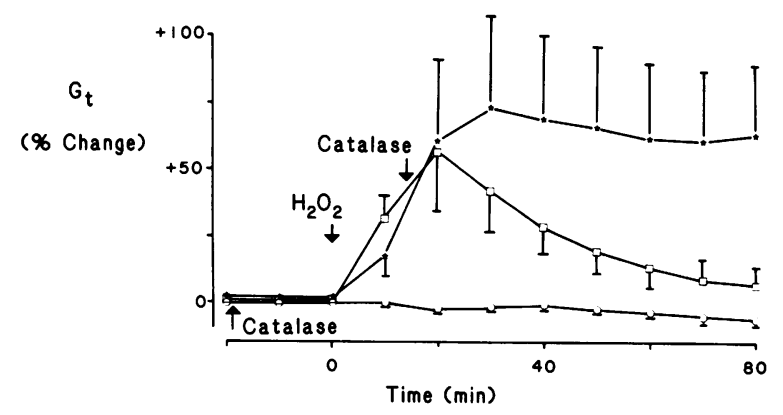

Figure 4. Reversibility of the increase in $\mathrm{G}_{1}$ produced by $\mathrm{H}_{2} \mathrm{O}_{2}$. Three groups of tissues were studied; all three received $\mathrm{H}_{2} \mathrm{O}_{2}\left(8 \times 10^{-4} \mathrm{M}\right)$ at time zero. One group of four tissues (circles) was pretreated with catalase $\left(1,000 \mathrm{U} \cdot \mathrm{ml}^{-1}\right)$ at the time indicated; one group of four (stars) received no catalase; and one group of five (squares) received catalase $\left(1,000 \mathrm{U} \cdot \mathrm{ml}^{-1}\right)$ after $\mathrm{H}_{2} \mathrm{O}_{2}$, at the time indicated. 

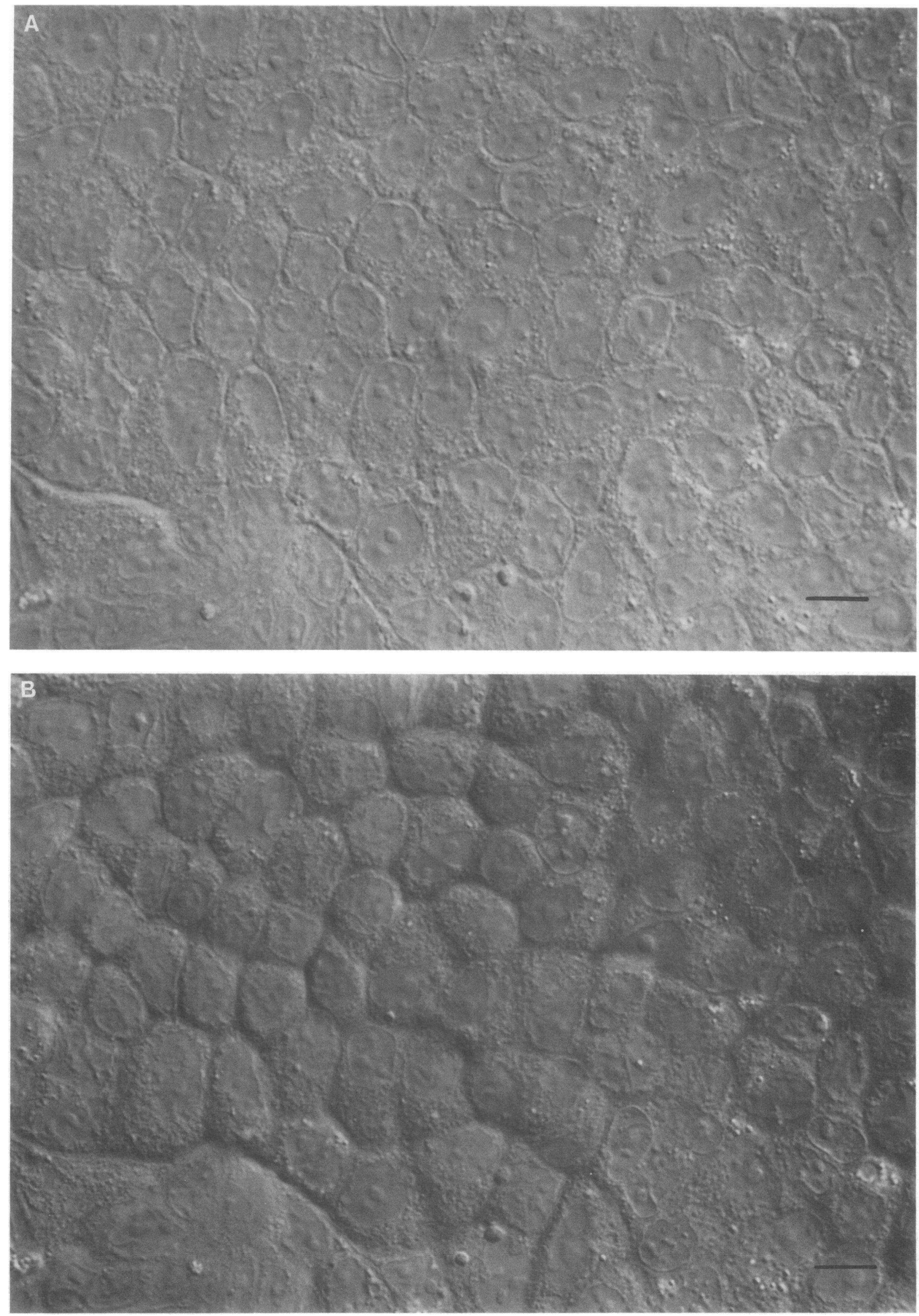


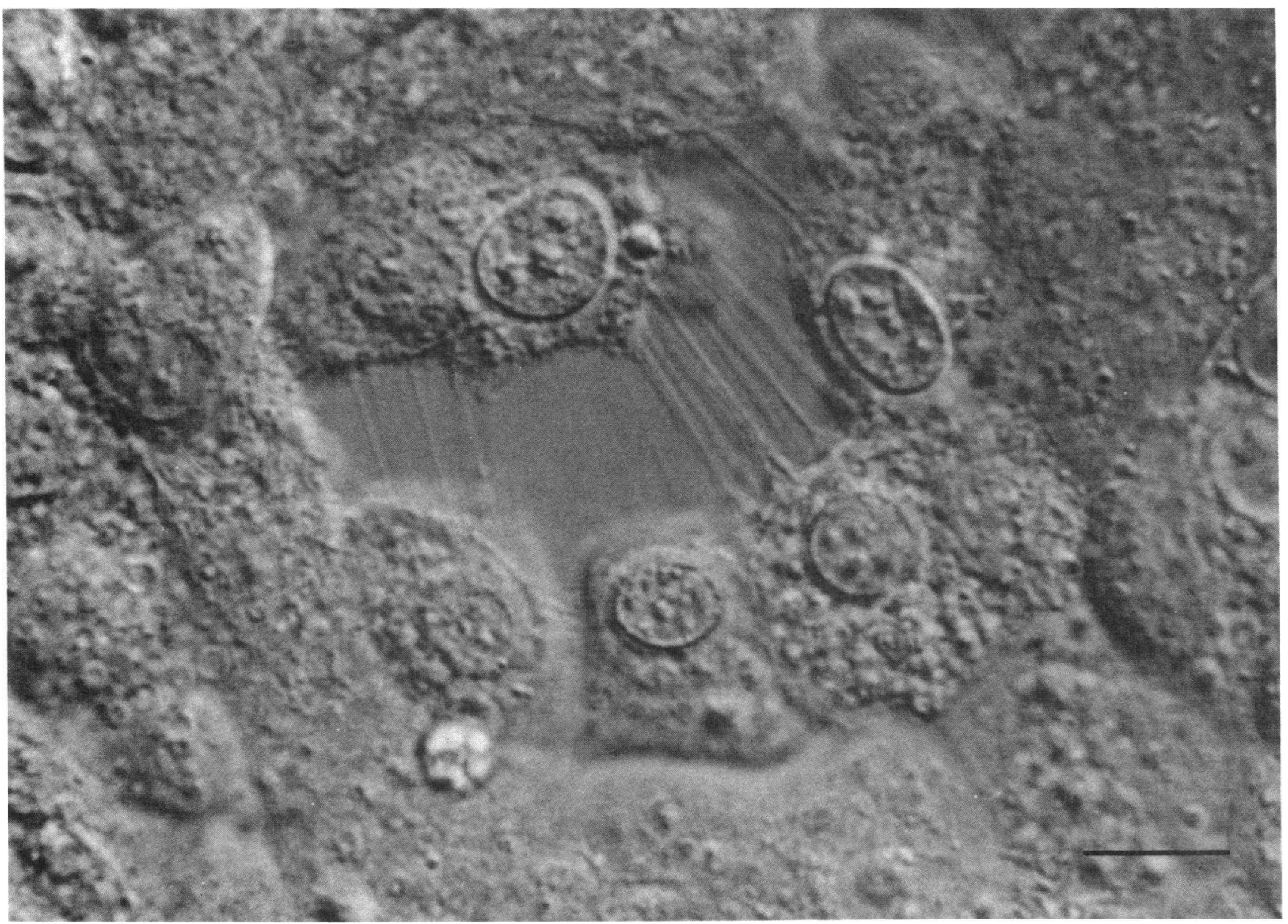

Figure 6. $\mathrm{H}_{2} \mathrm{O}_{2}$-induced separation of cells. The monolayer was perfused with $\mathrm{H}_{2} \mathrm{O}_{2}$ for $30 \mathrm{~min}$ and then normal perfusate for $50 \mathrm{~min}$. Bar, $10 \mu \mathrm{m}$.

occurred $\left(\sim 75-100 \%\right.$ increase in $\left.G_{t}\right)$, the changes were irreversible. Finally, if the concentration of $\mathrm{H}_{2} \mathrm{O}_{2}$ was large $(>4$ $\left.\times 10^{-3} \mathrm{M}\right)$, the $\mathrm{G}_{\mathrm{t}}$ did not decrease with catalase. Despite these caveats, the important point is that the functional increase in monolayer permeability was often reversible.

Oxidant-induced changes in cell shape. We also examined the effect of oxidants on the morphology of intact, living monolayers. To examine the effect of oxidants, the perfusion solution was switched to one containing $4 \mathrm{mM} \mathrm{H}_{2} \mathrm{O}_{2}$. Although this concentration is higher than was usually required to increase $G_{t}$, we observed minimal, if any, changes at lower concentrations. The structural response to $\mathrm{H}_{2} \mathrm{O}_{2}$ was very heterogeneous; many areas of the monolayers showed no discernible changes. When changes were observed, the most frequent finding was an increase in the thickness of the central portion of the cell, around the nucleus, with thinning toward the cell margins. Thus, the monolayer took on the appearance of hills (the central part of the cell) with surrounding valleys. This feature is shown in Fig. $5 A$, which was taken during perfusion with Ringers, and Fig. $5 B$, which was taken after 13 min of perfusion with $\mathrm{H}_{2} \mathrm{O}_{2}$-containing solution. There were no apparent morphologic changes during the time frame of these experiments in monolayers which did not receive $\mathrm{H}_{2} \mathrm{O}_{2}$.
A less common, but striking finding was a pulling apart of neighboring cells, leaving only thin strands connecting the adjoining cells. Fig. 6 shows a microscopic field of cells exposed to $\mathrm{H}_{2} \mathrm{O}_{2}$ for 30 min and then perfused with normal perfusate for $50 \mathrm{~min}$. One cell partially pulled away from its neighbors, leaving only thin filamentous connections. This field also shows that such changes were very heterogeneous; the other cells in the field have not pulled apart. We were unable to identify any specific distinguishing features of cells that showed these changes.

We also found that $\mathrm{H}_{2} \mathrm{O}_{2}$ sometimes caused only a partial separation of cells in the monolayer. The series of photomicrographs in Fig. 7 shows that in some cases, cells separated at their basolateral surface but maintained contact at the apical margin, presumably in the area of the junctional complex. Fig. 7, $A-E$, all show the same field. The shallow depth-of-focus of differential interference contrast microscopy allowed us to see that the portion of the cells closest to the coverslip had pulled apart. As shown in Fig. $7 \mathrm{~A}$, at the base of the cell only the most central part of the cell is still in tight contact with the coverslip, with ridges and strands of membrane radiating from the center. At a slightly higher level of focus (Fig. 7, $B$ and $C$ ), it is clear that the cells are separated, but bands of cytoplasm still connect the cells. In contrast, by focusing at two levels toward the apical
Figure 5. Effect of $\mathrm{H}_{2} \mathrm{O}_{2}$ on MDCK monolayers. $A$ was taken during perfusion with regular Ringers and $B$ was taken 13 min after the addition of $\mathrm{H}_{2} \mathrm{O}_{2}$ to the perfusate. Both photomicrographs were taken at a level of focus through the nucleus. Note that after $\mathrm{H}_{2} \mathrm{O}_{2}$, there is thinning at the margins of the cells as compared with before $\mathrm{H}_{2} \mathrm{O}_{2}$, giving the appearance of hills with valleys in between. Bar, $10 \mu \mathrm{m}$. 

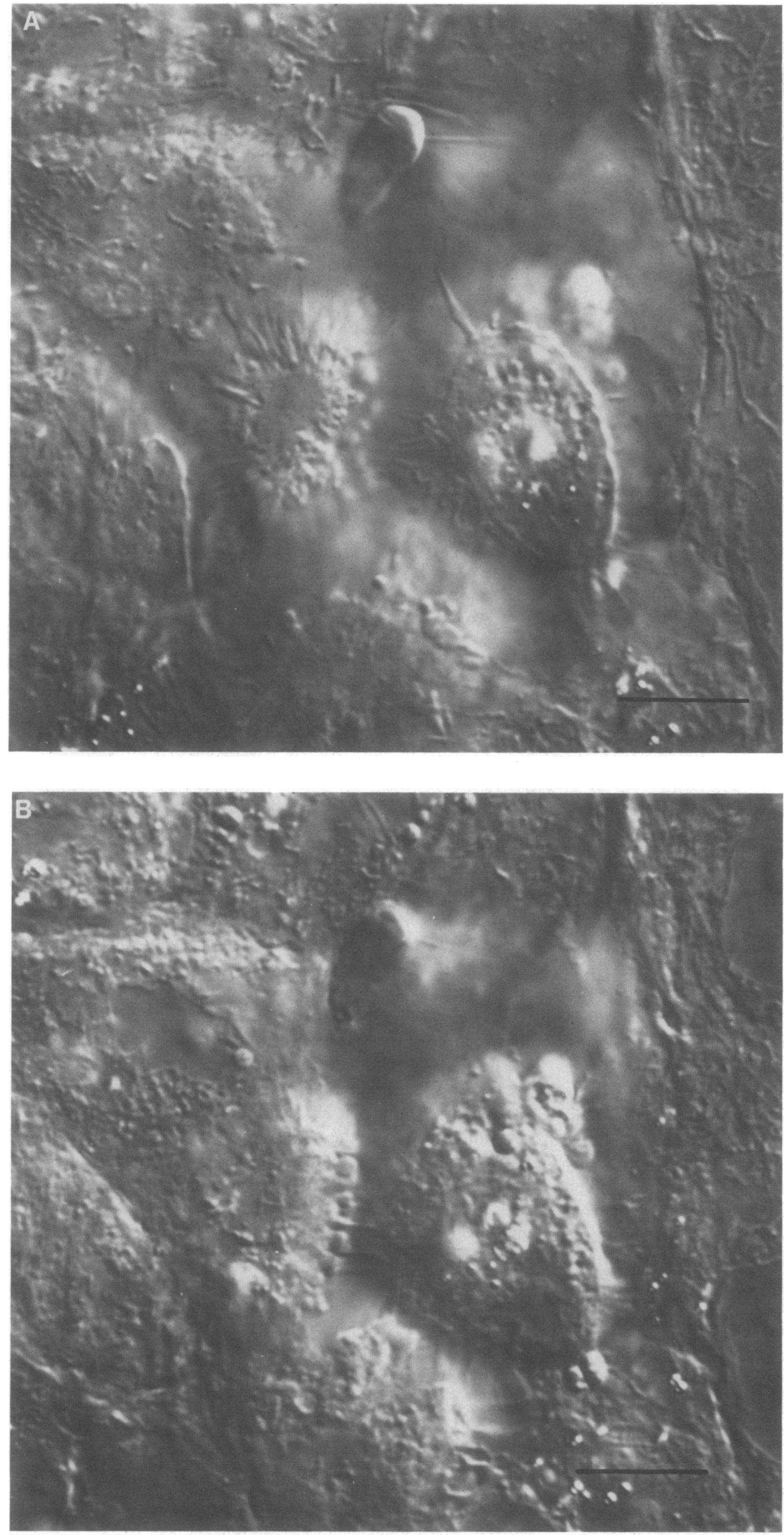

Figure 7. $\mathrm{H}_{2} \mathrm{O}_{2}$-induced separation of cells. $\mathrm{H}_{2} \mathrm{O}_{2}$ caused cells to pull apart at their basolateral but not apical area of contact. $A-E$ were taken of the same field with each photomicrograph taken at a slightly higher level of focus. $A$ was taken at the base of the cells just above the coverslip, and $E$ was taken at the apical surface. Note that in this particular instance, one of the cells showing retraction is a mucroplicated cell, as indicated by the pattern of ridges on its surface. Bar, $10 \mu \mathrm{m}$. 

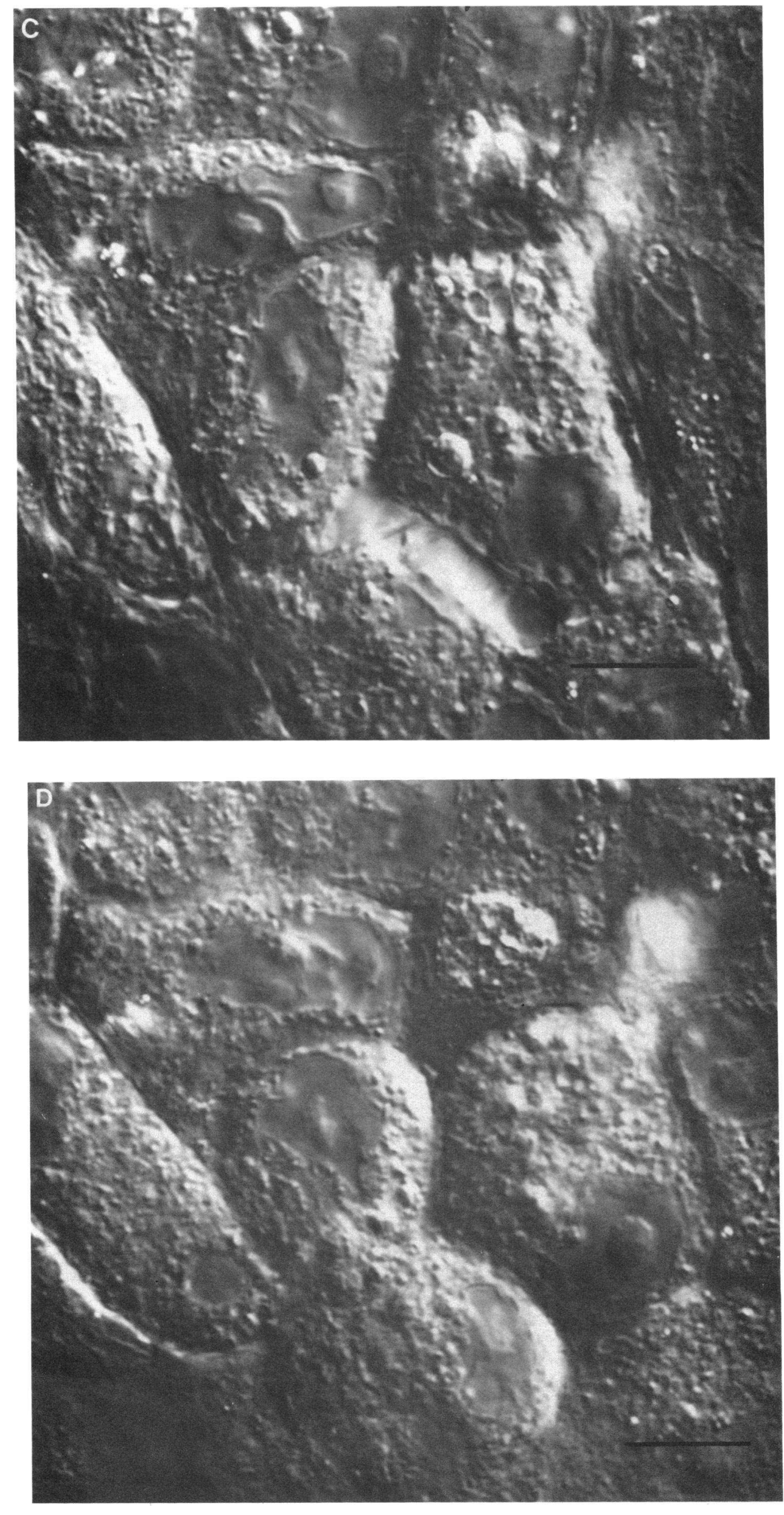

Figure 7 (Continued) 


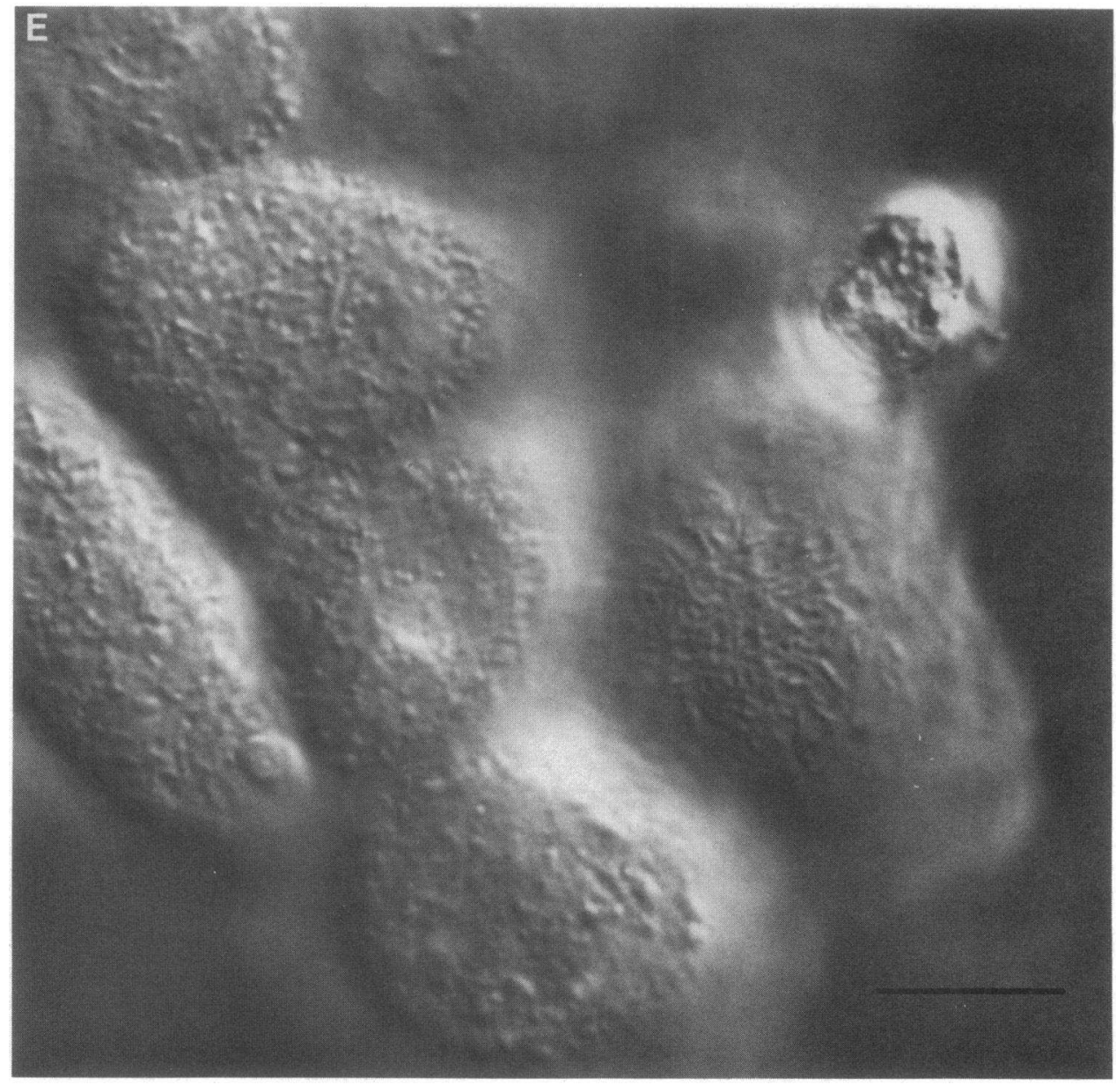

Figure 7 (Continued)

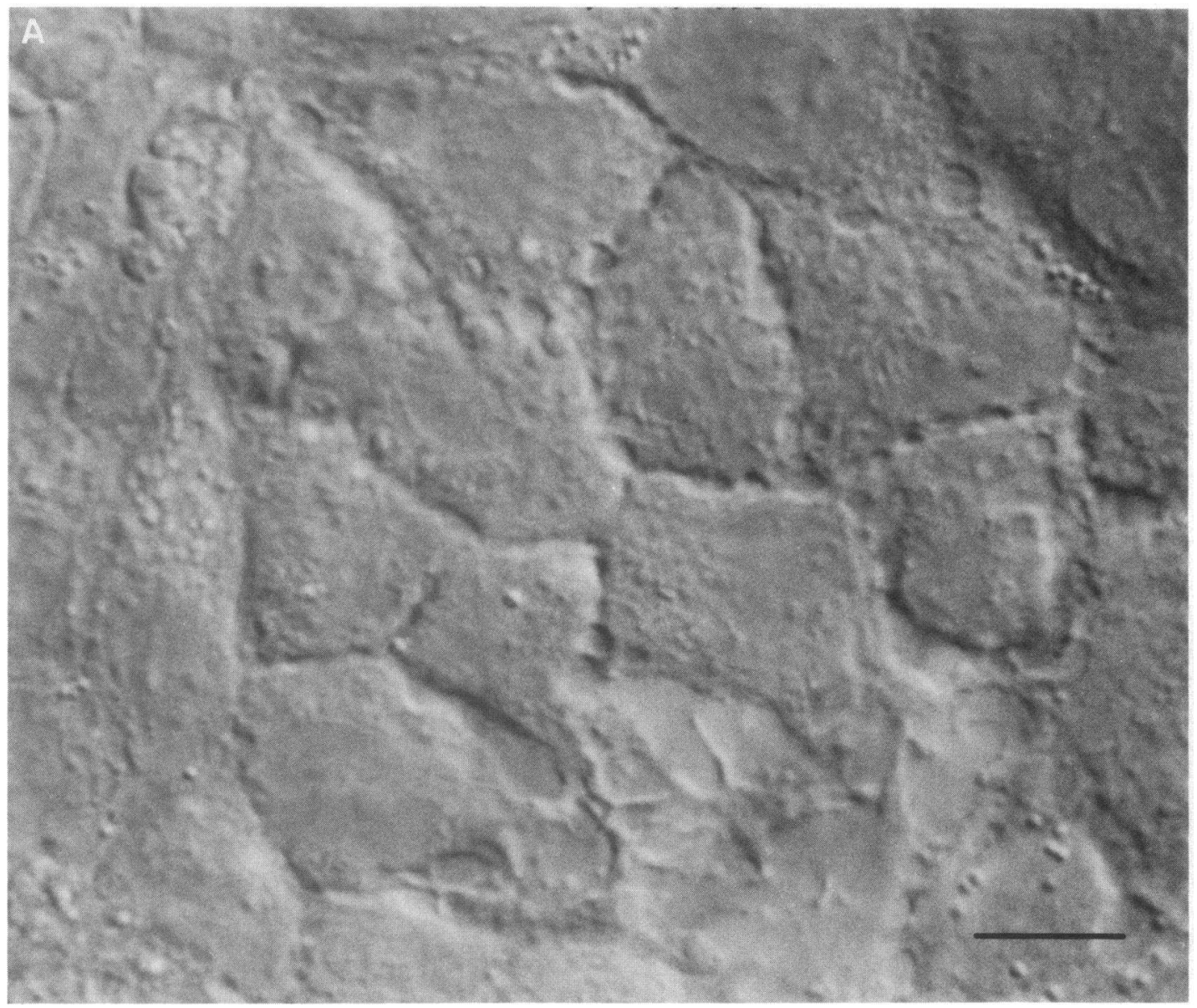

Figure 8. Reversibility of the effect of $\mathrm{H}_{2} \mathrm{O}_{2}$ on cellular morphology. The same field is shown throughout. $A$ was taken 7 min after beginning perfusion with $\mathrm{H}_{2} \mathrm{O}_{2}$. The monolayer was perfused with $\mathrm{H}_{2} \mathrm{O}_{2}$ for a total of $11 \mathrm{~min} . B$ and $C$ were taken 4 and 35 min after discontinuing the $\mathrm{H}_{2} \mathrm{O}_{2}$ perfusion. Bar, $10 \mu \mathrm{m}$. 

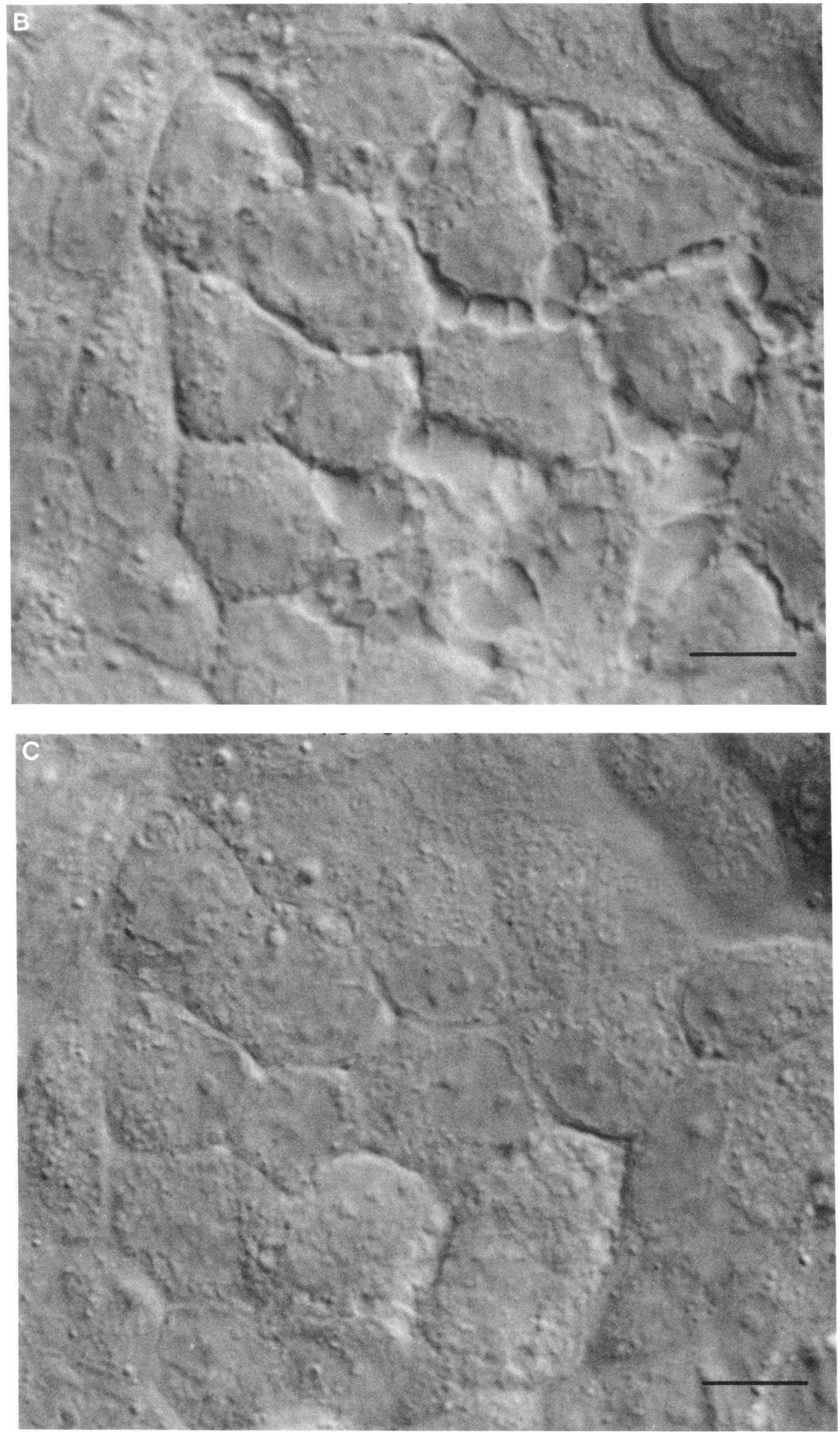

Figure 8 (Continued) 

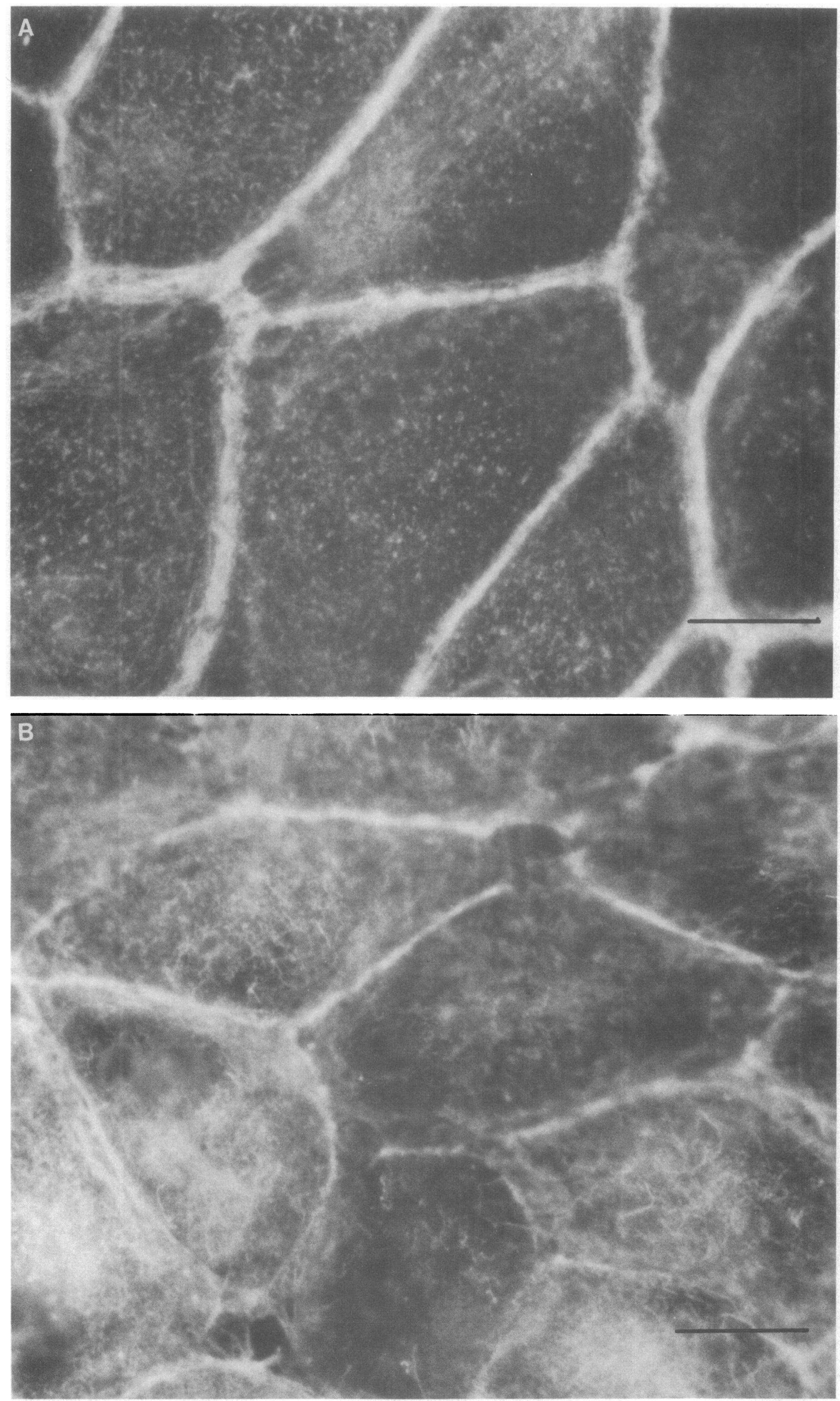

Figure 9. $\mathrm{H}_{2} \mathrm{O}_{2}$-induced changes in actin cytoskeleton. Factin was visualized by staining with rhodamine phallicidin and then observation with epifluorescence. $A$ shows the pattern observed in cells that were not exposed to $\mathrm{H}_{2} \mathrm{O}_{2}$. The cells shown in $B$ and $C$ were exposed to varying concentrations of $\mathrm{H}_{2} \mathrm{O}_{2}$ before fixation: $B, 2 \mathrm{mM}$ $\mathrm{H}_{2} \mathrm{O}_{2}$ for $15 \mathrm{~min}$; $C$, $8 \mathrm{mM} \mathrm{H}_{2} \mathrm{O}_{2}$ for 15 min; $D, 4 \mathrm{mM} \mathrm{H}_{2} \mathrm{O}_{2}$ for $90 \mathrm{~min}$. Bar, 10 $\mu \mathrm{m}$. 

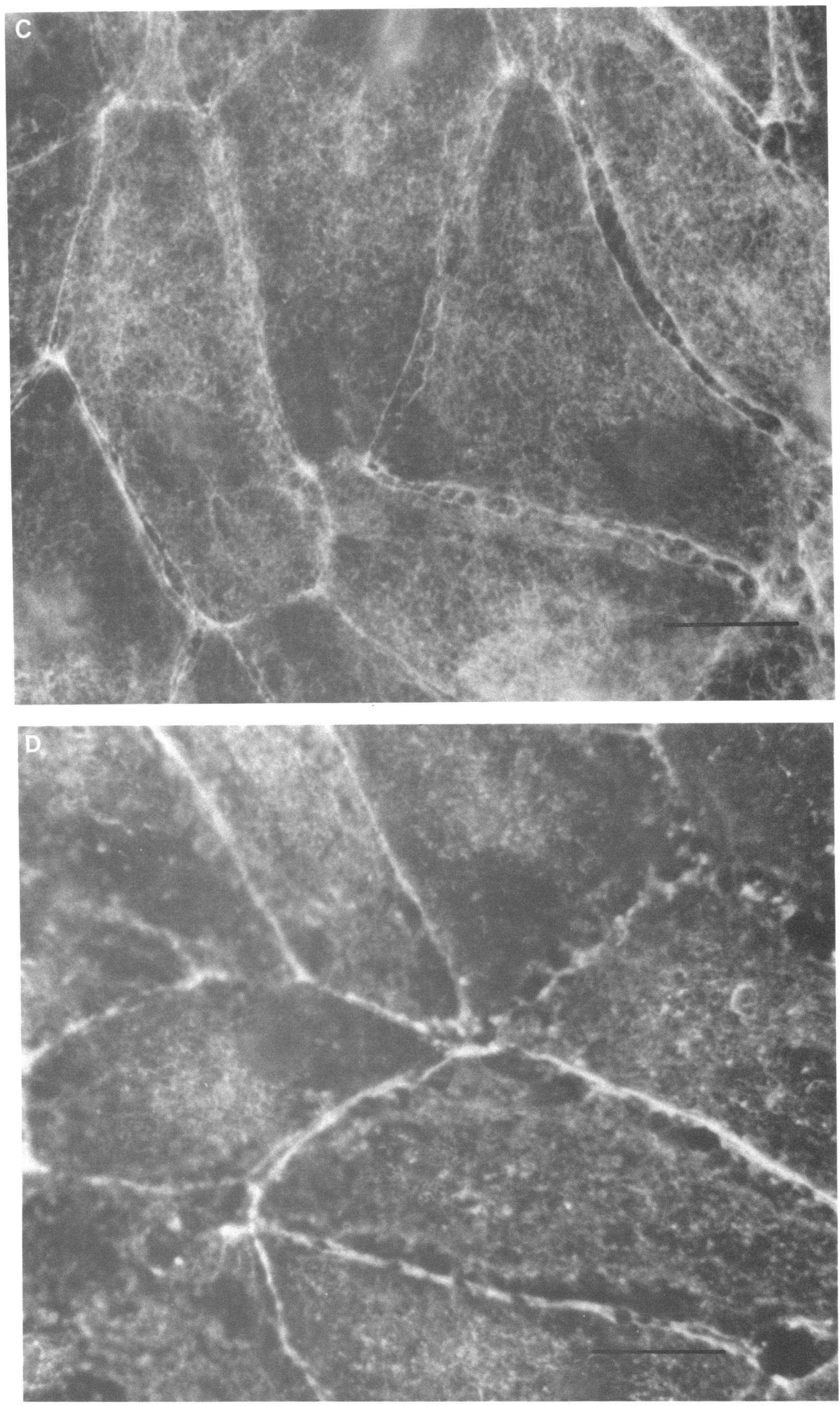

Figure 9 (Continued) 
surface of the cells (Fig. 7, $D$ and $E$ ), it becomes apparent that the cells are still in contact at the apical surface.

The separation, or pulling apart of the cells, was sometimes reversible when we switched from $\mathrm{H}_{2} \mathrm{O}_{2}$-containing perfusate back to regular Ringer's solution. Fig. 8 is a series of photomicrographs taken of the same microscopic field and shows the reversible changes. Fig. $8 \mathrm{~A}$ shows cells which have been perfused with $4 \mathrm{mM} \mathrm{H}_{2} \mathrm{O}_{2}$ for $7 \mathrm{~min}$ and have clearly begun to separate along their margins. The separation is not complete; there are still strands of membrane which give the appearance of a series of blebs. After 11 min of perfusion with $\mathrm{H}_{2} \mathrm{O}_{2}$-containing media, we switched to the regular Ringers. Fig. $8 \mathrm{~B}$ was taken $4 \mathrm{~min}$ after stopping $\mathrm{H}_{2} \mathrm{O}_{2}$; the areas of separation have increased in size. Over the course of the next $35 \mathrm{~min}$ the cells gradually resealed their lateral margins: Fig. $8 C$ shows that the cells are no longer retracted. This time course is similar to that observed for the reversible changes in $G_{t}$ (Figs. 3 and 4).

Oxidant-induced alterations in cell cytoskeleton. Our findings presented so far indicate that oxidants increase junctional permeability, a change accompanied by alterations in cell shape. In light of previous studies that have stressed the importance of the cell cytoskeleton in the maintenance of both junctional permeability and cell shape (19), we felt that it was important to determine if the changes we observed were associated with changes in the cell cytoskeleton.

Fig. 9, $A-D$, shows the cellular pattern of f-actin as stained by rhodamine phallicidin. Fig. $9 A$ shows a monolayer that did not receive oxidants. Note the speckled pattern of cytoplasmic staining and the thick continuous junctional area. Fig. 9, $B-D$, show changes in cells exposed to oxidants. As in the other studies, there was some heterogeneity in the observed changes. The cells shown in Fig. $9 \mathrm{~B}$ were exposed to $2 \mathrm{mM} \mathrm{H}_{2} \mathrm{O}_{2}$ for $15 \mathrm{~min}$ before they were fixed. Several changes in the fluorescent pattern are apparent. First, the speckled cytoplasmic pattern has been replaced by a more reticular pattern. Second, the junctional band of staining is much thinner. Third, discontinuities, or a beading of the junctional band, have become apparent. Fig. $9 C$ shows a monolayer exposed to $8 \mathrm{mM} \mathrm{H}_{2} \mathrm{O}_{2}$ for $15 \mathrm{~min}$. The changes described in Fig. $9 \mathrm{~B}$ are more pronounced, and, in addition, in many areas there is a pulling apart of the junctional complex, giving the appearance of parallel thin bands of staining. Fig. 9 $D$ shows a monolayer exposed to $4 \mathrm{mM} \mathrm{H}_{2} \mathrm{O}_{2}$ for $90 \mathrm{~min}$; the changes in $\mathrm{f}$-actin distribution are very pronounced. In addition to the thinning and beading of the junctional band of staining, we observed a perijunctional clear space, in which it appeared that the actin had pulled back away from the junction between cells.

\section{Discussion}

The results of this study demonstrate that reactive oxygen metabolites increase the transepithelial permeability of a cultured epithelium. The increase in permeability was associated with morphologic changes in the cells that resulted in separation of adjacent cells and alterations in the pattern of the cell's actin cytoskeleton. Both the increase in electrical conductance and the morphologic changes could be reversed with modest exposure to oxidants, but with high concentrations, or sustained exposure to lower concentrations, both effects became irreversible.

Considerable evidence indicates that reactive oxygen molecules, derived from inflammatory cells or directly added to cells, can contribute to cellular injury $(5,6,20,21)$. While different reports implicate different molecular species as the effector molecule, many have suggested that $\mathrm{H}_{2} \mathrm{O}_{2}$ or a derivative of $\mathrm{H}_{2} \mathrm{O}_{2}$ is critically involved and that $\mathrm{O}_{2}^{-}$contributes to injury only as a precursor of $\mathrm{H}_{2} \mathrm{O}_{2}$ or hydroxyl radical, $\mathrm{OH}$. Our observations that $\mathrm{H}_{2} \mathrm{O}_{2}$, added directly or generated with glucose oxidase, increased epithelial conductance also suggest an important role for $\mathrm{H}_{2} \mathrm{O}_{2}$ in this process. The finding that xanthine and xanthine oxidase increased transepithelial conductance is also consistent with an effect of $\mathrm{H}_{2} \mathrm{O}_{2}$ because $\mathrm{O}_{2}^{-}$, generated by xanthine-xanthine oxidase, can dismute to $\mathrm{H}_{2} \mathrm{O}_{2}$. However, our observations do not allow us to determine what the exact effector molecule(s) is/are.

The junctional complex, including the tight junction, is one of the main features that distinguishes epithelial cells from other cell types. The junction between cells serves as a barrier to movement of solutes and water across the epithelial sheet. The permeability of the paracellular pathway (the pathway between the cells, through the tight junctions and lateral intercellular space) varies with different cell types. However, in most "leaky" and some "tight" epithelia, the paracellular route provides the predominant conductive pathway across the epithelium (22). Several aspects of our studies suggest that oxidants increased the permeability of this pathway. First, oxidants increased the transepithelial electrical conductance in an epithelium in which the predominant transepithelial conductive pathway is paracellular $(10,12,13)$. Second, oxidants increased the permeability of the epithelium to mannitol, which predominately crosses the epithelium via an extracellular route $(15,18)$. Third, the morphologic changes appeared to involve the area of contact between the cells. While we cannot exclude the possibility that the permeability of the cell membranes may also change in response to oxidants, our evidence would suggest that the increase in transepithelial permeability is predominantly localized to the paracellular pathway, thereby making the tight junctions a prime suspect for the site of action.

The morphologic changes we observed were heterogeneous. It is possible that the functional changes in $G_{t}$ and transmonolayer mannitol flux also resulted from heterogeneous changes in the paracellular path. Alternatively, there may have been more homogeneous oxidant-induced functional alterations in the junctions between cells that were below the resolution of our optical techniques. In examining the cells, we were unable to identify any specific features of the cells which underwent shape changes or any subpopulation of cells that were involved. Certainly, if high concentrations or prolonged exposure to oxidants were used, more widespread changes would be seen. However, we chose to use oxidant exposures that would allow us to observe the dynamics and reversibility of the functional and morphological alterations in living cells. In addition to heterogeneity in the morphological response, we saw heterogeneity in the functional $\left(G_{t}\right)$ response. Both the time course of response to oxidants and the absolute magnitude of the changes varied from monolayer to monolayer, as is apparent from an examination of Figs. 1-3. Such variability in the response to oxidants is not surprising, given the variability in the functional properties of MDCK monolayers at different passages, even between different sublines at the same passage number (12). Moreover, variability in the response to oxidant injury has also been observed in other tissue types $(23,24)$.

This is the first study that shows reversible changes in epithelial function and structure after exposure to oxidation. The ability of the epithelium to decrease its permeability, or "reseal," 
indicates that our observations are not solely the result of cell death. Rather, they indicate a dynamic interaction between cells and oxidants. The cells must contain the regenerative mechanisms required to repair the alterations in paracellular permeability.

While many studies have documented injurious effects of oxidants on cells, most have used cell death as a measure of injury. However, several studies have shown that oxidants can alter cell metabolism independent of cell death. A recent report from Ager and Gordon (25) demonstrated increased ${ }^{86} \mathrm{Rb}$ efflux and release of adenine nucleotides by endothelium before cell death. In addition, oxidants have been reported to inactivate or uncouple membrane enzymes (9) and oxidized fatty acids have been reported to act as calcium ionophores (26). The only other study to directly evaluate the effect of oxidants on epithelial cells is that of Parsons et al. (27). In a preliminary communication, they reported that $\mathrm{H}_{2} \mathrm{O}_{2}$ produced a reversible decrease in the electrical resistance of a monolayer of MDCK cells, supporting our observations. A reversible increase in the permeability of cultured endothelial monolayers exposed to oxidants has also been reported (23), providing further evidence that cells can recover from finite levels of oxidant injury.

Previous studies with MDCK cells (19) have demonstrated the importance of the cell cytoskeleton, particularly the microfilaments, in the maintenance of cell shape and the integrity of both junctional function and structure. In this study we found that oxidants alter both junctional function (electrical conductance) and the appearance of the cell cytoskeleton, as evidenced by the distribution of f-actin. These two findings lead us to speculate that oxidants increase transepithelial electrical conductance by disrupting the cell cytoskeleton, which then alters junctional structure and function. These changes may not be uniquely related to oxidants, but may also result from other injurious agents. For example Lopez-Vancell et al. (28) found that infection of MDCK cell monolayers with influenza or vesicular stomatitis virus resulted in an increase in the conductance of the paracellular pathway.

This study does not define the link between oxidants and an alteration of paracellular permeability. However, it is possible that an oxidant-mediated increase in intracellular calcium might be the mechanism involved in the changes in cell function and structure. This speculation is based on the work of others. First, as indicated above, oxidation of membrane lipids may allow them to function as calcium ionophores, thereby increasing intracellular calcium (26). Consistent with this suggestion is the recent finding that when hepatocytes have accumulated $\mathrm{Ca}$, they are more susceptible to oxidative injury (29). Second, MartinezPalomo and coworkers (30) have shown that increases in intracellular calcium can reversibly increase the permeability of MDCK monolayers and reversibly alter cell morphology, presumably by an effect of $\mathrm{Ca}$ on the cell cytoskeleton (23).

The results of this study may be of value in understanding the pathophysiology of a variety of diseases involving oxidant injury. Ischemia, radiation therapy, and neutrophil-mediated inflammation result in release of reactive oxygen molecules, often ones in close proximity to epithelia. The adult respiratory distress syndrome may be a syndrome in which oxidants play a major role in alterations of alveolar epithelial as well as capillary endothelial integrity $(4,31,32)$. The model system we have described should be a useful tool to explore the mechanisms by which oxidants sublethally injure cells, the processes by which epithelial cells recover from an oxidant injury, and the mecha- nisms by which oxidants alter epithelial barriers during acute and chronic inflammation.

\section{Acknowledgments}

The secretarial assistance of Deanna Ollendick and Mary Uhl is greatly appreciated.

This work is supported by a Program Project grant from the National Institutes of Health (HL-14388), and by research grants from the American Heart Association, the Council for Tobacco Research, and the Veterans Administration.

\section{References}

1. Del Maestro, R. F. 1980. An approach to free radicals in medicine and biology. Acta Physiol. Scand. 492:153-168.

2. McCormick, J. R., M. M. Harkin, K. J. Johnson, and P. A. Ward. 1981. Suppression by superoxide dismutase of immune complex-induced pulmonary alveolitis and dermal inflammation. Am. J. Pathol. 102:5561.

3. Johnson, K. J., J. C. Fantone, J. Kaplan, and P. A. Ward. 1981. In vivo damage of rat lungs by oxygen metabolites. J. Clin. Invest. 67: 983-993.

4. Tate, R. M., K. M. VanBenthuysen, D. M. Shasby, R. F. McMurtry, and J. E. Repine. 1982. Oxygen radical mediated permeability edema and vasoconstriction in isolated perfused rabbit lungs. Am. Rev. Respir. Dis. 126:802-806.

5. Weiss, S. J., J. Young, A. LoBuglio, A. Slivka, and N. F. Nimeh. 1981. Role of hydrogen peroxide in neutrophil-mediated destruction of cultured endothelial cells. J. Clin. Invest. 68:714-721.

6. Clark, R. A., and S. J. Klebanoff. 1975. Neutrophil-mediated tumor cell cytotoxicity: role of the peroxidase system. J. Exp. Med. 141:14421447.

7. Kellogg, E. W., and I. Fridovich. 1977. Liposome oxidation and erythrocyte lysis by enzymically generated superoxide and hydrogen peroxide. J. Biol. Chem. 252:6721-6726.

8. Mittal, C. K., and F. Murad. 1977. Properties and oxidative regulation of guanylate cyclase. J. Cyclic Nucleotide Res. 3:381-391.

9. Garner, W. H., M. H. Garner, and A. Spector. 1983. $\mathrm{H}_{2} \mathrm{O}_{2}$-induced uncoupling of bovine lens $\mathrm{Na}^{+}, \mathrm{K}^{+}$-ATPase. Proc. Natl. Acad. Sci. USA. 80:2044-2048.

10. Cereijido, M., E. Stefani, and A. Martinez-Palomo. 1980. Occluding junctions in a cultured transporting epithelium: structural and functional heterogeneity. J. Membr. Biol. 53:19-32.

11. Cereijido, M., J. Ehrenfeld, I. Meza, and A. Martinez-Palomo. 1980. Structural and functional membrane polarity in cultured monolayers of MDCK cells. J. Membr. Biol. 52:147-159.

12. Husted, R. F., M. J. Welsh, and J. B. Stokes. 1985. Variability of functional characteristics of MDCK cells. Am. J. Physiol. (Cell Physiol.). In press.

13. Stefani, E., and M. Cereijido. 1983. Electrical properties of cultured epithelioid cells (MDCK). J. Membr. Biol. 73:177-184.

14. Postlethwaite, A. E., R. Snyderman, and A. H. Kang. 1976. The chemotactic attraction of human fibroblasts to a lymphocyte-derived factor. J. Exp. Med. 144:1188-1203.

15. Welsh, M. J., and J. H. Widdicombe. 1980. Pathways of ion movement in the canine tracheal epithelium. Am. J. Physiol. 239:F215F221.

16. Shasby, D. M., S. S. Shasby, J. M. Sullivan, and M. J. Peach. 1982. Role of endothelial cell cytoskeleton in control of endothelial permeability. Circ. Res. 51:657-661.

17. Maridonneau, I., P. Braquet, and R. P. Garay. 1983. $\mathrm{Na}^{+}$and $\mathrm{K}^{+}$transport damage induced by oxygen free radicals in human red cell membranes. J. Biol. Chem. 256:3107-3113.

18. Dawson, D. C. 1977. $\mathrm{Na}$ and $\mathrm{Cl}$ transport across the isolated turtle colon: parallel pathways for transmural ion movement. J. Membr. Biol. 37:213-233. 
19. Meza, I., G. Ibarra, M. Sabanero, A. Martinez-Palomo, and M. Cereijido. 1980. Occluding junctions and cytoskeleton components in a cultured transporting epithelium. J. Cell Biol. 87:746-754.

20. Harlan, J. M., J. D. Levine, K. S. Callahan, B. R. Schwartz, and L. A. Harker. 1984. Glutathione redox cycle protects cultured endothelial cells against lysis by extracellularly generated hydrogen peroxide. J. Clin. Invest. 73:706-713.

21. Ward, P. A., G. O. Till, R. Kunkel, and C. Beauchamp. 1983. Evidence for role of hydroxyl radical in complement and neutrophildependent tissue injury. J. Clin. Invest. 72:789-801.

22. Diamond, J. M. 1974. Tight and leaky junctions of epithelia. Fed. Proc. 33:2220-2224.

23. Shasby, D. M., S. E. Lind, S. S. Shasby, J. C. Goldsmith, and G. W. Hunninghake. 1985. Reversible oxidant induced increases in permeability of cultured endothelium: alterations in cell shape and calcium homeostasis. Blood. 65:605-614.

24. Harlan, J. M., J. D. Levine, K. S. Callahan, B. Schwartz, and L. A. Harker. 1984. Glutathione redox cycle protects cultured endothelial cells against lysis by extracellularly generated hydrogen peroxide. J. Clin. Invest. 73:706-713.

25. Ager, A., and J. L. Gordon. 1984. Differential effects of hydrogen peroxide on indices of endothelial cell function. J. Exp. Med. 159:592603.
26. Serhan, C., P. Anderson, E. Goodman, P. Dunham, and G. Weissmann. 1981. Phosphatidate and oxidized fatty acids are calcium ionophores. J. Biol. Chem. 256:2736-2741.

27. Parsons, P. E., G. R. Cott, R. J. Mason, and P. M. Henson. 1984. Reversible oxidant "injury" of an epithelial cell monolayer. Fed. Proc. 43:777A. (Abstr.)

28. Lopez-Vancell, R., G. Beaty, E. Stefani, E. E. Rodriquez-Boulan, and M. Cereijido. 1984. Changes in paracellular and cellular ionic permeabilities of monolayers of MDCK cells infected with influenza or vesicular stomatitis virus. J. Membr. Biol. 81:171-180.

29. Thor, H., P. Hartzell, and S. Orrenius. 1984. Potentiation of oxidative cell injury in hepatocytes which have accumulated $\mathrm{Ca}^{2+} . \mathrm{J}$. Biol. Chem. 259:6612-6615.

30. Martinez-Palomo, A., I. Meza, G. Beaty, and M. Cereijido. 1980. Experimental modulation of occluding junctions in a cultured transporting epithelium. J. Cell Biol. 87:736-745.

31. Till, G. O., K. J. Johnson, R. Kunkel, and P. A. Ward. 1982. Intravascular activation of complement and acute lung injury. J. Clin. Invest. 69:1126-1135.

32. Bernard, G. R., W. D. Lucht, M. E. Niedermeyer, J. R. Snapper, M. L. Ogletree, and K. L. Brigham. 1984. Effect of $N$-acetylcysteine on the pulmonary response to endotoxin in the awake sheep and upon in vitro granulocyte function. J. Clin. Invest. 73:1772-1784. 